\title{
Engagement and Retention of the Millennial Generation in the Workplace through Internal Branding
}

\author{
Gaye Özçelik ${ }^{1}$ \\ ${ }^{1}$ Faculty of Economics and Administrative Sciences (FEAS), Okan University, İstanbul, Turkey \\ Correspondence: Gaye Özçelik, Business Administration, FEAS, Okan University, 34959, İstanbul, Turkey. Tel: \\ 0090-216-6771630-ext. 2829. E-mail: gaye.ozcelik@okan.edu.tr
}

Received: December 11, 2014

Accepted: January 4, $2015 \quad$ Online Published: February 27, 2015

doi:10.5539/ijbm.v10n3p99

URL: http://dx.doi.org/10.5539/ijbm.v10n3p99

\begin{abstract}
Within the strong competitive world of organizations, the provision of exceptional customer experience is the key driver of performance. In this context, many organizations invest in their brands and, try to create a positive image of them, not only in the minds of their external customers, but also in those of their employees, because they are conceptualized as internal customers. Effective involvement of the human resources function for helping them to internalize the brand identity in their work behaviors has been an emerging area of study over the last decade. This has brought forward the notion of internal branding-a strategy through which organizations encourage all their employees to become involved in the nurturing of a brand through their engagement. Meanwhile, the organizational workforce is dynamic and constantly changing owing to a younger cohort entering the workplace. This renewal in the workforce demographics has led to differences in their characteristics and work orientations and consequently, has changed the rules of engagement. This paper outlines some emerging evidence about the HR-internal branding relationship. It brings together diverse sources of literature from organizational and generational studies to illustrate the characteristics and work orientations of the Millennials and the potential challenges posed by this generation. This article also provides the readers with specific recommendations for developing new practices and policies designed to attract, develop and retain this cohort so that it contributes internally to strong brand engagement.
\end{abstract}

Keywords: internal branding, the millennial generation, human resource management, employee engagement, employee retention

\section{Introduction}

Within the strong competitive world of organizations, the provision of exceptional customer experience is the key driver of performance. This experience can be developed and maintained through the ability of organizations to deliver a quality of service rather than the pure provision of physical goods (King \& Grace, 2007). In this context, many organizations utilize and invest in their brands, try to create a positive image of them, not only in the minds of their external customers, but also in those of their employees, because they are conceptualized as internal customers. An internal marketing approach is crucial as it allows for the communication of the brand to internal customers, namely the workforce of an organization.

The workforce of organizations is dynamic and constantly changing with elderly employees gradually retiring and younger cohorts graduating from university, about to start their professional careers. Westerman and Yamamura (2007) point out that values, preferences and demands of new generations entering the workplace can lead to misunderstandings as well as communicational concerns that influence employee productivity, motivation and engagement, which result in problems of employee retention and turnover.

Our examination of the generational challenges posed for human resource management with respect to employee branding references, especially regarding the new net generation, called the Millennials or Generation Y, seeks to identify any discrepancies between them and Generation X, who are still pursuing their careers in the workplace. Some researchers have uncovered distinct perspectives concerning Generation X and Generation Y, whereas others have found none, arguing that they have a similar pragmatic outlook on life (Shaw \& Fairhurst, 2007). Nevertheless, the exposure of each successive generation to a more intensive and pervasive Internet and other technological utilities could lead to their shifting their work engagement faster than previous generations.

This paper presents a general assessment of the working attitudes of the so called "Millenials" or "Generation Y 
employees" from the perspective of internal branding, which is a highly effective strategy for delivering the corporate branding message to employees, for it can create a strong sense of belongingness with emotional buy-ins. Forward looking organizations have been investing a lot to attract, recruit, motivate and retain the Millennials. The role that employees can play in enhancing the brand promise and the involvement of the human resource function in incorporating the brand concept into all their development programs (Aurand et al., 2005) will be examined by considering the characteristics and work orientations of the Millennials and the potential challenges posed by their arrival in the workplace. The paper also provides the readers with specific recommendations for developing new practices and policies designed to attract, develop and retain this cohort as well as how to contribute internally to strong brand engagement.

\section{An Overview of Internal Branding}

\subsection{The Concepts of Brand and Branding}

Kotler and Armstrong (2011) have defined the concept of brand as "a name, term, sign symbol or a combination of these, that identifies the maker or seller of the product", whereas Bergstrom, et al. (2002) consider it to be "the sum of all perceived functional and emotional aspects of a product or service." Raj and Jyothi (2011) articulate that branding is a process of developing psychological structures and impressions received by the target market that help them organize their knowledge about a particular product, service or organization. As such, brands are not only names and symbols, but also a key element in the company's relationships with consumers, which is underpinned by the latter's perceptions and feelings about a product and its performance. As Walter Landor (n.d.), a pioneer of branding once stated "products are created in the factory; brands are created in the mind."

Branding is the process of adding a higher level of emotional meaning to a product or a service, which increases its value to customers and other stakeholders (Bergstrom, et al., 2002). It is important to build brand-oriented and emotional affinity with the brand among all stakeholders, who are the relevant audiences of the brand and, whose lives are touched somehow by it. Branding provides opportunities both for shaping the organization's relationship with customers and also opportunities for shaping the organization's relationship with its employees (Raj \& Jyothi, 2011).

\subsection{Definition of Internal Branding}

Brands possess meanings in the context of "character, attitudes, motivations and emotions", not only for the external customers, but also for the internal employees who directly or indirectly work with the brand and reflect its values to external customers and the public at large (Mahnert \& Torres, 2007). This concept rests on the assumption that customers' traditional association with a brand through the design, packaging and/or specific product attributes, etc. is no longer sufficient for companies to achieve successful brand performance (Khan, 2009). For, today a brand is much more than these things as it should be a customer experience delivered by internal employees to external customers (Raj \& Jyothi, 2011).

Internal branding is defined as a set of strategic activities of a corporation to provide and ensure intellectual and emotional employee buy-in (Mahnert \& Torres, 2007). Internal branding perspective helps employees develop congruent and compatible brand-oriented behaviors such that they accommodate feelings of commitment to the brand throughout their daily work activities (Özçelik \& Fındıklı, 2014). Through internal branding, organizations can lead employees develop an internally and genuinely belief, such that their day-to-day activities and behaviors help build positive external outlook of their companies and help ensure external customer satisfaction (Khan, 2009; Punjaisri \& Wilson, 2007; Henkel et al., 2007). Applying the IB perspective to the employees by treating them as the internal customers of the organization via implementing various human resources processes, policies and strategies help them develop a positive attitude towards the brand and brand values (Raj \& Jyothi, 2011).

\section{Developing Employee Engagement and Employee Retention through Internal Branding}

Organizations with an internal branding approach try to position a specific brand image in the minds of their employees, who are then expected to project this through brand consistent employee behaviors, both within and outside the firm. The more the workforce consistently delivers a customer experience aligned with the brand promise, the higher the competitive advantage. Concerning this issue, engagement of employees is more important than ever before, for it goes much further than just simple employee satisfaction, involving feelings of: deep commitment, pride, honor and pioneering about the organization's brand (Ahmad, et. al, 2014). Engaged employees are highly motivated in their jobs and emotionally attached to the organization with great enthusiasm for the success of their employer. They often do more than what is written in their employment contract (Kompaso \& Sridevi, 2010). William Kahn (1990), the generator of the concept "employee engagement", has 
argued that this is a form of workplace identity, whereby the more employees believe in what they do and identify themselves with their work, the more determined they are to contribute to the success of their organization.

Employee engagement can be enhanced by internal branding efforts (Ahmad et al., 2014) in that encouraging employees to live the brand before placing it in front of customers helps to provide a positive customer experience. Moreover, internal branding fosters motivation in employees, provides them with a clear direction in their work and increases their commitment to the organization, all of which contribute to the success of the business strategy. Engagement strategies that focus on creating emotions of inspiration and pride in employees will increase employee retention (Bhatla, 2011; Robinson, 2006; Schaufeli \& Bakker, 2004). Cascio (2014) also asserts that from a talent perspective, the most successful organizations today are those that succeed in employee retention by developing positive employer brands, innovative approaches to the design and execution of human resource development (HRD) activities and those that provide performance management strategies that maximize employee potential.

\subsection{The Role of Human Resources in Internal Branding}

The concept of internal branding is widely discussed in the studies of marketing scholars and professionals, being seen as part of an internal marketing approach aimed at attracting, developing and retaining employees by satisfying their work and development needs. That is, internal marketing targets the firm's employees and as such involves not only the function of marketing, but also the processes of HR. In fact, employees seem to have a more positive attitude towards the brand and are more likely to incorporate this image into their work activities when there is some degree of HR involvement in the internal branding process (Memon \& Kolachi, 2012). Hence, the successful promotion of the internal branding doctrine may be as dependent on HR initiatives as on those developed in the marketing department (Aurand, Gorchels, \& Bishop, 2005). Internal branding requires a broad integrative framework across marketing, corporate management and human resource management (Khan, 2009; Punjaisri, 2007). If firms can provide the alignment of marketing and HR processes, employees can better identify themselves with the brand values and project these in their attitudes and behaviors (Vallaster \& De Chernatony, 2003; Burmann \& Zeplin, 2005).

Many employee branding programs focus on the traditional HR activities of attraction, recruitment, communications, motivation and retention. It can be very beneficial when the ideas of branding from communications and marketing are introduced into the process of human resources, such that there is effective development of value propositions for employees (Martin et al., 2005). An important role that HR should adopt in relation to internal branding is during the recruitment and selection process, when rather than focusing purely on technical and/or operational skills, there should be a search for value congruence between employees, the organization and the brand. Regarding which, it is recommended to recruit employees with values that fit with those of the organization (Punjaisri \& Wilson, 2007). Another salient function of HR is to integrate the brand concept into all employee training and development programs with the collaboration of the marketing department (Punjaisri \& Wilson, 2007). As indicated in some studies, only a proportion of employees report that what they learn from structured formal training is transferred to the reality in the workplace, because they mostly learn on the job. Consequently, training programs need to be established that take into account the fact that learning takes place in a range of environments and not just during face to face instruction. Moreover, evidence has been found that working and learning are closely linked in that learning by doing generates specific competencies in people that are necessary for them to perform effectively (Asha \& Jyothi, 2013). To implement successful internal branding, HR should develop effective reward and recognition schemes, for they have been found to improve employee commitment to the organization and to the brand (Khan, 2009; Punjaisri \& Wilson, 2007). Moreover, the greater the reward they receive for their work efforts, the higher the likelihood of job satisfaction.

HR professionals and academicians agree that employee engagement is also strengthened when organizations become aware of the fluidity of the labor market. Today, employees have developed different views on work-life balance (WLB) and they can easily switch to other organizations when the conditions they desire are not met (Memon \& Kolachi, 2012). In fact, WLB has been found to be a crucial factor for HRM in promoting individual engagement and organizational effectiveness (Shankar \& Bhatnagar, 2010). Consequently, many organizations today try to offer different work arrangements so as to develop a better work-life balance between the domains of work and "the rest of life" (Guest, 2002) in order to improve employee retention and engagement. These interventions that enhance employee branding can deliver competitive advantage to organizations (Shankar \& Bhatnagar, 2010). 


\section{Millennials: A New Generation in the Workplace}

Organizations are becoming increasingly dynamic as older members of the workforce approach retirement and younger members start their careers. This is because the older generational cohort worked during an era when people usually had a job for life, which certainly is not the case nowadays. Firms and their internal marketers should therefore be aware of the needs, wants and work preferences of different generations by undertaking comparative benchmarking studies across these generations (Reisenwitz \& Iyer, 2009). Strauss and Howe (1991) have defined a generation as "the aggregate of all people born over a span of roughly twenty years or about the length of one phase of life: childhood, young adulthood, midlife, and old age." So, a generation is a group sharing an "age location in history", such that they face key historical events and social trends during the same period of life. Each generation that experiences the same events within the same time span having similar values and world views, shring cultural, political and economic experience, is called a generational cohort.

The oldest generational cohort still in the workplace today is the baby boomer generation, being those who were born between the years 1946 and 1964, but they are nearing retirement age, if they have not already left the workforce. The generation following the baby-boomers is called Generation X, being born between 1965 and 1980 and who generally prospered in their careers. The next generation, those born between 1981 and 2000, is known as the Millennium Generation, Net Generation or Generation Y. This is the group who have already or are about to start their careers, depending on their year of birth.

Members of Generation X and the Millennium Generation have been exposed to different historical, economic and social events than older cohorts and therefore have different characteristics and expectations (Reisenwitz \& Iyer, 2009). It is argued that members of the Millennium Generation are different from preceding groups both as employees and as consumers (Shaw \& Fairhurst, 2008). That is, this generation possesses distinctive characteristics with respect to their expectations from the employment experience with regards to learning requirements, attitudes to career and self-development, work orientation, and engagement. In particular, it has been observed that with its recent entrance into the workforce, employee turnover rates have become higher than before (Kelleher, 2011; Westerman \& Yamamura, 2007).

\subsection{Characteristics, Styles and Employment Expectations of the Millennials}

The Millennium Generation is the demographic group that has recently been in higher education and is now entering the workplace. Millennials are characterized as having high levels of self-confidence and self-reliance; they are independent, individualistic, and socially active and like to work in teams (Shih \& Allen, 2007). They are the children of nurturing and protective mothers and fathers, who have responded to their every emotional, educational and physical need. Moreover, they have praised their children for every small effort they have made. Consequently, when they enter the world of work, they also have high expectations of recognition, approval and being rewarded by their employers. For similar reasons, they also have a strong desire to be led with clear directions and be well supported by their managers (Martin, 2005).

The parents of Generation $Y$ have experienced both career progress and job losses due to economic crises and the downsizing of organizations owing to the introduction of new automated technologies. As a result, the Millennials perceive that employers and work can be unreliable and hence, it is best that they do not over-commit to the organizations they work for. As a result, they emphasize self-development by searching for opportunities to learn and grow, with the goal of rapid career advancement rather than life-long employment; they want to make the most of the opportunities provided in the workplace.

In addition, Millennials are technology literate and are very comfortable with the internet world, as they have grown up in an environment of technology and thus, are familiar with mobile phones, lap-top computers, real-time media and communications (Shaw \& Fairhurst, 2008). This lowers their level of patience and also engenders in them immediate feedback expectations from their managers.

\subsection{Millennials and Challenges for Internal Branding: Implications and Recommendations for Human Resources Management}

From the preceding discussion it becomes clearly apparent that engaging this new group of the workforce through different development programs has become an important challenge (Shaw \& Fairhurst, 2008) for marketing, HR professionals and corporate management. At present, organizations employ individuals from the aforementioned different generational cohorts as follows:

- Baby Boomers, senior, experienced, more traditional employees or managers who are about to complete their professional business life; 
- Generation X, constituting the majority of the present day workforce, enjoying higher income levels and possible career advancement;

- Millennials, or Generation Y, quite recent graduates, who have started to occupy the workplace in the last few years.

When the demands of a new generation entering business as a new workforce are not fully acknowledged, this can lead to misunderstandings, miscommunications and unproductivity, thus leading to lower employee commitment and higher turnover intentions (Westerman \& Yamamura, 2007; O'Bannon, 2001; Adams 2000). Considering the divergence of the attitudes and work values of Millennials when compared to the Baby Boomers and Generation X, as explained above, there could well be further problems regarding retention and engagement of this potential workforce.

From a human resource management perspective, the different outlook of the Millennials, with respect to what they expect from their employment and employers, are forcing organizations to consider whether they need to develop innovative approaches to the design and delivery of these policies. Organizations should fine tune their strategies to address the needs of the Millennials. To this end, corporate management and HR should endeavour to understand their motivators and preferences so as to be able to develop appropriate recruitment processes, selection tools, training and development techniques, rewards systems and to implement them effectively (Westerman \& Yamamura, 2007).

The challenge therefore, is how can we create a culture amongst young engaged employees of a "passion for work" and willingness to make extra effort to make a successful corporate brand, in a climate where they are highly responsive to external attractive opportunities. That is, one of the most important issues facing organizations today regarding Millennials is turning them into brand pioneers so as to increase their level of engagement.

\subsubsection{Recruitment and Selection}

Human resource management when exercised effectively can contribute significantly to the development of an internal branding approach, which attracts, develops, and keeps employees by ensuring their engagement and satisfaction of needs in relation to work-related products. For instance, given that the Millennium Generation places great store in integrity and consistency, any promises given during the recruitment process must be delivered by the employer or otherwise they will soon be gone (Prokopeak, 2013). Moreover, HR departments used to rely on traditional skill pools, such as top universities and/or people who have certain credentials, which are highly indirect indicators of future employee performance. Today, forward thinking recruiters have started to focus on targeting individuals with respect to their personal values and skill-sets (Dahlstroem, 2011).

\subsubsection{Performance Management}

Gilbert (2011) contends that effective performance management is one of the most frequent engagement drivers. Millennials expect to have continuous, immediate and more frequent feedback about their performance than previous generations so they can evaluate their own progress. Consequently, HR professionals should design performance management systems that provide continuous feedback and coaching on a quarterly or even more frequent basis, goal setting and appraisal (Cascio, 2014). To this end, effective mentoring programs could be established to provide ongoing feedback. Orrell (2009) notes that more than 60 percent of Generation Y employees ask for a hearing with their managers at least once a day. In addition, the feedback process should not only involve positive or negative criticism, but also be clear and specific, leaving no room for misunderstanding (Gilbert, 2011), for it has been noted that they need to be constantly guided by their supervisors (Reisenwitz \& Iyer, 2009).

\subsubsection{Training, Development and Mentoring Policies}

With respect to training and career management, providing career opportunities and challenging meaningful assignments are perceived to be more critical to Millennials than life-long employment (Shaw and Fairhurst, 2008). They would like to work for organizations that constantly foster their skills development, but want to keep control of planning their own careers. Fast track leadership programs should be designed for those who show promise and HR departments should make sure that Millennials have opportunities for challenging assignments, job enrichment, and even international projects. Giving personal acknowledgement, ongoing training and consistent frequent feedback as well as recognition of achievement are other crucial key factors that drive employee engagement and retention. In general, the less the organization is bounded by strict vertical hierarchies and training programs, the easier it will be to hire Millennials (Behrens, 2009) as they have an aversion to traditional HR practices. Another important recommendation is to use "reverse mentoring", whereby 
young Millennials who have less overall experience owing to their youth, play the role of trainer for senior and more experienced employees in particular areas, such as computer technologies, viral marketing, cutting-edge design and the like. In so doing, Millennials, who also have an expectancy of rising faster in their career than previous generation cohorts (Barnes, 2009), will be provided with the chance to participate and contribute from day one at work (Behrens, 2009).

\subsubsection{Technology Utilization}

Effective modern HR departments contribute to enhancing employee learning, development and retention through engagement with technological innovations for delivering these processes. The provision of such media as technology-delivered instructions, text-based courses, educational games, video conferencing, chat rooms and interactive distance learning as well as social-learning tools, such as wikis, Facebook, Twitter and Yammer, is attractive for Millennials, as they like to keep up with the latest developments in their field of business. In addition, allowing for flexible access to lifelong learning to this generation who are technologically-savvy, is intrinsically motivating.

\subsubsection{Flexible Working Arrangements}

This is a generation that values flexibility in working arrangements and work-life balance constitutes an important dimension that they expect from their organization. They ask for "freedom and flexibility to get the job done in their own way and their own pace" without going through the layers of bureaucracy (Martin, 2005, p.40). Reisenwitz and Iyer (2009) similarly mention that Y'ers would like to have flexibility in completing their tasks and responsibilities (Reisenwitz \& Iyer, 2009). However, when they are asked to sacrifice the rest of their life for work, they choose family and friends over work (Shaw \& Fairhurst, 2008). This preference is increasing as technological advancements, especially high speed internet, are becoming standard in the home and hence, employees believe that they need not be physically at work throughout scheduled work hours. Prokopeak (2013) also argues that this is the first generation that will strongly question the 9-to-5 workday ethic, because technology frees them from doing work at work. Therefore, in order to attract and retain Y'ers companies will need to organize work schedules that permit them to work flexi-time, telecommute and/or work from home.

\subsubsection{Career Advancement Opportunities and Employee Retention}

Research has shown that the younger the employees are, the more desirous they are to move quickly upwards on the career ladder and they have greater expectations of achievement and success than a high salary. Similarly, Hewlett, Sherbin and Sumberg (2009) report that Generation Yers rate rewards like recognition from their company or boss and a steady rate of promotion at least if not more important than remuneration. This is because they are impatient to be informed that they have made a worthwhile contribution to the organization they work for. Consequently, organizations should readily give positive feedback to this generation regarding the ways in which their work has enhanced the success of the firm (Reisenwitz \& Iyer, 2009). Moreover, their level of retention is likely to be strongly positively associated with a work environment that provides job challenges as well as opportunities for taking an active role in the development of their careers and skills (Smola and Sutton, 2002) or otherwise they will choose to leave. Prokopeak (2013) points out that while baby boomers leave their employment on average after seven years and for Generation X this figure is every five, Millennials only remain at their place work for an average of two years (Prokopeak, 2013). Regarding which, recent research shows that Millennials are inclined to leave the organization when they are not provided with new learning opportunities (Reisenwitz \& Iyer, 2009). Therefore, the pathway for leadership development and the criteria necessary for leadership success should be frequently communicated to them by senior staff and line managers (Barnes, 2009).

\section{Conclusion}

There has been much discussion regarding the role HR departments should play in internal branding initiatives so as to ensure that employees are motivated in the care and nurturing of a brand, develop a deeper understanding of it and internalize its identity in their work attitudes and behaviors. Internalizing the brand from the perspective of employees requires highly effective, intrinsically motivating human resource management policies and practices, that develop a sense of belongingness and emotional attachment to the organization and hence to the brand.

Many employee branding programs focus on the traditional HR activities of attraction, recruitment, communications, motivation and retention. In addition to these, employees should be provided with value propositions via effective communication. Moreover, rather than taking pure technical/operational skills into consideration when recruiting, those potential employees whose values fit with the values of the organization should be given priority. In addition, transforming the concept of training into one of learning by doing will help 
cultivate specific competencies and developing effective financial reward packages linked to the acquisition of these is also recommended.

As there is a never-ending state of transformation in seeking new ways of doing business, there is also one regarding workforce demographics, whereby organizations are affected by the preferences and differing values of succeeding generations. Consequently, corporate management and HR departments must be able to understand and accommodate the expectations of new generations, so as to enhance the value of the firm. One of the big challenges for management in today's business environment is to identify the engagement drivers and threats of the Millennials. There are significant differences between this generation and the previous ones-Generation X and baby boomers-who are still present in the workforce, in terms of their characteristics, working styles and employment expectations (Gilbert, 2011). Consequently, they need to fine tune their HR strategies so as to take into account the needs of the three different cohorts of employment age.

As has been explained, Millennials have distinct workplace needs and motivating factors when compared to Generation X and baby boomers. They are attracted to companies that provide flexible work hours, a fun work environment as well as opportunities for project diversity, career advancement and further learning. Family and personal lives being afforded a relatively degree of privacy and work-life balance are also highly valued by this group. In particular, they develop feelings of loyalty when they are provided with opportunities to work from home and are afforded flexi-time arrangements. These benefits help them develop engagement feelings and passion for their work which will enhance internal branding. Therefore, corporate management and HR departments should strive to comprehend their motivators and preferences so as to be able to develop appropriate recruitment processes, selection tools, training and development techniques, rewarding systems and implement them effectively.

Given this paper has taken a descriptive perspective, additional empirical research is needed to identify more comprehensively the distinctive work environment preferences and values of the Millennials so as to be able to engender in them feelings of pride and inspirational buy-ins for their organization and its products. Of particular benefit, would be expanding the studies to different types of organizations so as to elicit whether any occupational differences or variations in terms of corporate culture exist. Such investigation is particularly important, for it will uncover whether it is appropriate to make generalizations regarding the personal development needs for Millennials. Consideration should be given not only to Millennials to create a positive environment with employee buy-in, but also to intergenerational differences in relation to the characteristics and expectations of the different cohorts so as to reinforce their living the brand. In sum, effective implementation of internal branding strategies through the contributions of HR policies that address intergenerational distinctions will help employees to become emotionally attached to their organization with greater enthusiasm for the success of both themselves and their employer than were it otherwise.

The study contributes to the literature by portraying through a review of extant work how HR functions can be modified so as to enhance employee engagement and effective internal branding. In addition, the paper also focuses on the Millennials, a new generation of workers who have brought their own particular values and preferences, which thus represent new challenges to the human resources management of organizations and their internal branding strategies. Those that manage to understand and accommodate the shifting values and expectations of this recently arrived workforce will be able to win "the war for talent".

\section{References}

Adams, S. J. (2000). Generation X: how understanding this population leads to better safety programs. Professional Safety, 45, 26-39.

Adamson, A. P. (2006). Brand Simple: How the Best Brands Keep it Simple and Succeed. USA: Palgrave MacMillan Ltd.

Ahmad, N., Iqbal, N., Kanwal, R., Javed, H., \& Javed, K. (2014). The mediating role of employee engagement in relationship of internal branding and brand experience: Case of service organizations of Dera Ghazi Khan. International Journal of Information, Business and Management, 6(4), 26-41.

Aurand, T. W., Gorchels, L., \& Bishop, T. R. (2005). Human resource management's role in internal branding: An opportunity for cross-functional brand message synergy. Journal of Product and Brand Management, 14(3), 163-169. http://dx.doi.org/10.1108/10610420510601030.

Barnes, G. (2009). Guess Who's Coming to Work: Generation Y. Are You Ready for Them? Public Library Quarterly, 28, 58-63. http://dx.doi.org/10.1080/01616840802675457.

Behrens, W. (2009). Managing Millennials: They're Coming to a Workplace Near You. Marketing Health 
Services, 19-21.

Bhatla, N. (2011). To study the employee engagement practices and its effect on employee performance with special reference to ICICI and HDFC bank in Lucknow. International Journal of Science and Engineering Research, 2, 1-7.

Bergstrom, A., Blumenthal, D., \& Crothers, S. (2002). Why Internal Branding Matters: The Case of Saab. Corporate Reputation Review, 5(2), 133-142. http://dx.doi.org/10.1057/palgrave.crr.1540170

Burmann, C., \& Zeplin, S. (2005). Building Brand Commitment: A Behavioral Approach to Internal Brand Management. Journal of Brand Management, 12(4), 279-300.

Cascio, W. F. (2014). Leveraging employer branding, performance management and human resource development to enhance employee retention. Human Resource Development International, 17(2), 121-128. http://dx.doi.org/10.1080/13678868.2014.886443

Dahlstroem, C. (2011). Matchmaking Emloyers with Employees: the Era of Personality Targeting. Journal of Corporate Recruiting Leadership, 10-12. http://www.ere.net/wp-content/uploads/2011/03/crl0311.pdf

Gilbert, J. (2011). The Millennials: A New Generation of Employees, a new set of Engagement Policies. IVEY Business Journal. Retrieved from http://iveybusinessjournal.com/topics/the-workplace/the-millennials-a-new-generation-of-employees-a-new -set-of-engagement-policies\#.VIayiDGsVqU

Henkel, S., Tomczak, T., Heitmann, M., \& Herrmann, A. (2007). Managing Brand Consistent Employee Behavior: Relevance and managerial control of behavioral branding. Journal of Product \& Brand Management, 16(5), 310-320. http://dx.doi.org/10.1108/10610420710779609

Hewlett, S., Sherbin, L., \& Sumberg, K. (2009). How Gen Y and Boomers Will Reshape Your Agenda. Harvard Business Review, 121-126.

Howe, N., \& Strauss, W. (1991). Generations: The History of America's Future, 1584 to 2069. New York: William Morrow \& Company Inc.

Kahn, W. A. (1990). Psychological conditions of personal engagement and disengagement at work. Academy of Management Journal, 33(4), 692-724. http://dx.doi.org/10.2307/256287

Kelleher, B. (2011). Employee Engagement and Retention. MWorld, 10(1), 36-39. Retrieved from http://connection.ebscohost.com/c/articles/58688917/employee-engagement-retention

Khan, B. M. (2009). Internal Branding: Aligning Human Capital Strategy with Brand Strategy, The Icfai University. Journal of Brand Management, 6(2), 22-26.

King, C., \& Grace, D. (2007). Internal Branding: Exploring the Employee's Perspective. Journal of Brand Management, 15, 358-372. http://dx.doi.org/10.1057/palgrave.bm.2550136

Kompaso, S. M., \& Sridevi, M. S. (2010). Employee Engagement: The Key to Improving Performance, International Journal of Business and Management, 5(12), 89-96. http://dx.doi.org/10.5539.v5n12p89

Kotler, P., \& Armstrong, G. (2012). Principles of Marketing. New Jersey, USA: Pearson Prentice Hall.

Landor, W. (n.d.). In Wikipedia, the Free Encyclopedia. Retrieved from http://en.wikipedia.org/wiki/Walter_Landor

MacLayert, N., McQuillian, P., \& Oddle, H. (2007). Internal Branding Best Practices Study. Canadian Marketing Association. Retrieved from http://www.odditie.com/pdf/InternalBranding.pdf

Mahnert, K. F., \& Torres, A. M., (2007). The Brand Inside: The Factors of Failure and Success in Internal Branding. Irish Marketing Review, 19(1/2), 54-63. Retrieved from https://www.dit.ie/media/newsdocuments/2008/neweditionofirishmarketingreview/06MahnertTorres.pdf

Martin, C. A. (2005). From high maintenance to high productivity what managers need to know about Generation Y. Industrial and Commercial Training, 37(1), 39-44. http://dx.doi.org/10.1108/00197850510699965

Martin, G., Beaumont, P., Doig, R., \& Pate, J. (2005). Branding: A New Performance Discourse for HR? European Management Journal, 23(1), 76-88. http://dx.doi.org/10.1016/j.emj.2004.12.011

Memon, M. A., \& Kolachi, N. A. (2012). Towards Employees Branding: A Nexus of HR \& Marketing. Interdisciplinary Journal of Contemporary Research in Business, 4(2), 46-61. 
Miles, S. J., \& Mangold, G. (2004). A Conceptualization of the Employee Branding Process. Journal of Relationship Marketing, 3(2/3), 65-87. http://dx.doi.org/10.1300/J366v03n02_05

O’Bannon, G. (2001). Managing our future: The Generation X Factor. Public Personnel Management, 30(1), 95-109.

Orrell, L. (2009). Millennials Into Leadership: The Ultimate Guide for Gen Y's Aspiring to Be Effective, Respected, Young Leaders at Work. USA: Intelligent Women Publishing, Ltd.

Prokopeak, M. (2013). How to Retain Your Millennial Workers. Workforce, 92(9). Retrieved September 30, 2009 http://www.workforce.com/articles/9338-interview-with-dan-schwabel-how-to-retain-your-millennial-work ers

Punjaisri, K., \& Wilson, A. (2007). The role of internal branding in the delivery of employee brand promise. Journal of Brand Management, 15, 57-70. http://dx.doi.org/10.1057

Raj, A, B., \& Jyothi, Dr. P. (2011). Internal Branding: Exploring the Employee Perspective. Journal of Economic Development, Management, IT, Finance and Marketing, 3(2), 1-27. http://dx.doi.org/10.1057/palgrave.bm.2550136.

Reisenwitz, T. H., \& Iyer, R. (2009). Differences in Generation X and Generation Y: Implications for the Organization and Marketers. The Marketing Management Journal, 19(2), 91-103.

Robinson, I. (2006). Human Resource Management in Organizations. London: Chartered Institute of Personnel Development (CIPD).

Schaufeli, W. B., \& Bakker, A. B. (2004). Job demands, job resources, and their relationship with burnout and engagement: A multi-sample study. Journal of Organizational Behavior, 25, 293-315. http://dx.doi.org/10.1002/job.248.

Severi, E., \& Ling, K. C. (2013). The Mediating Effects of Brand Association, Brand Loyalty, Brand Image and Perceived Quality on Brand Equity. Asian Social Science, 9(3), 125-137. http://dx.doi.org/10.5539/ass.v9n3p125

Shankar, T., \& Bhatnagar, J. (2010). Work-Life Balance, Employee Engagement, Emotional Consonance/Dissonance \& Turnover Intentions. The Indian Journal of Industrial Relations, 46(1), 74-87. http://dx.doi.org/10.2307/25741098

Shaw, S., \& Fairhurst, D. (2008). Engaging a New Generation of Graduates. Education and Training, 50(5), 366-378. http://dx.doi.org/10.1108/00400910810889057

Shih, W., \& Allen, M. (2007). Working with generation-D: Adopting and adapting to cultural learning and change. Library Management, 28(1/2), 89-100. http://dx.doi.org/10.1108/01435120710723572

Smola, K. W., \& Sutton, C. D. (2002). Generational differences revisiting generational work values for the new millennium. Journal of Organizational Behavior, 23, 363-382. http://dx.doi.org/10.1002/job.147

Vallaster, C., \& De Chernatony, L. (2003). Internalization of Services Brands: The Role of Leadership during the Internal Brand Building Process. Journal of Marketing Management, 21, 181-203. http://dx.doi.org/10.1362/0267257053166839

Westerman, J. W., \& Yamamura, J. H. (2007). Generational Preferences for Work Environment Fit: Effects on Employment Outcomes. Career Development International, 12(2), 150-161. http://dx.doi.org/10.1108/13620430710733631

\section{Copyrights}

Copyright for this article is retained by the author(s), with first publication rights granted to the journal.

This is an open-access article distributed under the terms and conditions of the Creative Commons Attribution license (http://creativecommons.org/licenses/by/3.0/). 